\title{
Prognostic factors in patients with Rocky Mountain Spotted Fever
}

Hiram J. Jaramillo-Ramírez, ${ }^{1}$ Jeremy J. Hernández-Ríos, ${ }^{2}$ Fátima M. Martínez-González, ${ }^{2}$ Luz A. Gutiérrez-Bañales, ${ }^{2}$ Eliot R. García-Valenzuela, ${ }^{2}$ J. Andrés Beltrán-López, ${ }^{2}$ Jorge L. Peterson, ${ }^{3}$ Flor M. Yocupicio, ${ }^{3}$ Rodolfo Ruíz-Luján. ${ }^{4}$

\begin{abstract}
Background: Rocky Mountain Spotted Fever (RMSF) is a disease with a high mortality rate, caused by Rickettsia rickettsii, a bacteria transmitted to humans by infected ticks. In 2008 there was a Rocky Mountain Spotted Fever (RMSF) outbreak in the city of Mexicali, México, resulting in an increased mortality rate amongst the area population. Methods: Case-series study of patients admitted to the General Hospital of Mexicali between 2014 and 2019 with a confirmed diagnosis of RMSF. Mortality was compared dividing the population on those $\leq 20$ and younger than $>21$ years of age. Results: A total of 129 patients' records during a 5-year period whose diagnosis was RMSF confirmed with PCR were included. Mortality was compared among patients admitted who were younger than 20 years of age with that among patients who were older than $>20$ years of age ( 61 versus 68 respectively), the latter being higher with an OR 4.2 (p<0.0001). Conclusion: RMSF in hospitalized patients has a high mortality rate in spite of early treatment in all age groups, without showing any predominance in gender. However, patients older than 20 years of age had a higher mortality rate than those younger than 20 years, without any predominance in gender.
\end{abstract}

Key Words: Rocky Mountain Spotted Fever; Rickettsia rickettsii; Mortality; Acute kidney injury; Necrosis (Source: MeSH-NLM).

\section{Introduction}

There are various disease-causing agents from the Rickettsia group, in North America and México some species prevail like R. rickettsii, R. akari, R. prowazekii, R. typhi y R. parkeri, the last one being a common infectious agent in the state of Arizona, United States of America (USA). and has been identified in ticks located in a city of México, however, there aren't reports of infected patients. ${ }^{1-2}$

Rocky Mountain Spotted Fever (RMSF) is a disease with a high mortality rate, caused by Rickettsia rickettsii, a bacteria transmitted to humans by infected ticks. ${ }^{1,4-5}$ This disease can be found in North and Central America, with a higher prevalence in México, Canada and United States of America. ${ }^{6}$ Ticks are the natural reservoirs of Rickettsia rickettsii, their life cycle lasts approximately two to three years. In the fall, adult females drop off the host to lay eggs which hatch into larvae and later attach to their first host. Then in the summer, larvae abandon the host and molt into nymphs. ${ }^{3}$ During the following spring, nymphs attach to the second host, they feed on it and drop off later in the summer. Nymphs molt into adults and attach to a third host to feed and mate on it. Lastly, females drop off the host in the fall to continue the cycle. ${ }^{14}$

RMSF was first described in early 1899 by Edward E. Maxey, he demonstrated an interest for the disease while reading an article called "Some observation on the so-called spotted fever of Idaho", and described it as "A febrile disease, clinically characterized by continuous moderately high fever, severe arthritic and muscular pains and petechial or purpuric eruption in the skin, appearing first on ankles, wrist and forehead". ${ }^{11,} 15$ Variation in clinical presentation interferes with diagnosis and with it the start of specific treatment, which increases mortality. Fever rose up to $38.9^{\circ} \mathrm{C}$ in $63 \%$ of patients during the first 3 days, and in $90 \%$ of patients during the first week. ${ }^{8}$ In $49 \%$ of patients skin lesions appeared during the first 3 days after fever developed, rising to $88-90 \%$ of patients during the $3^{\text {rd }}$ and $5^{\text {th }}$ day, these are representative signs of the disease. In severe cases, gangrene may appear in upper and lower extremities, as well as ears and scrotum.4 ${ }_{10}$ The combination of skin lesions by bacteria and vasculitis can result in skin necrosis and gangrene that may require amputation. ${ }^{7-8,12}$

Diagnosis is usually achieved with indirect immunofluorescence, or with high antibody levels. ${ }^{13}$ Other techniques like DNA amplification with polymerase chain reaction (PCR) have very sensitive and specific results, however, these techniques aren't always available in the country of México. ${ }^{13}$

The aim of the study is to demonstrate the benefit of an early treatment (initiation of treatment $\leq 5$ days after the beginning of symptoms), to identify risk factors that increase mortality rate amongst the population of the city of Mexicali, México, and the importance of an accurate diagnosis as a prognostic factor.

\section{Methods}

Case series of patients admitted to the General Hospital of Mexicali, a city located in northwestern México, between 2014 and 2019 with a confirmed diagnosis of Rocky Mountain Spotted Fever. The diagnosis was confirmed by polymerase chain reaction (PCR), which was processed by the Thermocycler Applied Biosystems 7500 Real-Time PCR System with llustraTM puRe Taq Ready-To-GoTM PCR Beads, according

1 MD. Internal Medicine, Chief Professor of the Internal Medicine academic course at the General Hospital of Mexicali, México

2 Medical Student. General Hospital of Mexicali. Faculty of Medicine UABC Mexicali, México.

3 MD. Internal Medicine resident General Hospital of Mexicali, México

${ }_{4}$ MD. Internal Medicine and Infectious Diseases, General Hospital of Mexicali, México

About the Author: Fátima M. Martínez-Conzález is currently a 7th year medical student of the Faculty of Medicine, Mexicali Campus, México, of a seven-year program. She is also part of a student fellowship program dedicated to community scientific research at the General Hospital of Mexicali.

Correspondence:

Hiram J. Jaramillo-Ramírez

Address: Calle del Hospital SN, Centro Cívico. Mexicali B.C. México.

Email: hiramjaramillo@yahoo.com.mx
Editor: Mihnea-Alexandru Găman \& Francisco Javier Bonilla-Escobar Submission: Jan 23, 2020 Revisions required: Feb 9, 2020 : Feb 28, 2020; Apr 7, 2020; Received in revised form: Feb 25, 2020; Mar 10, 2020; Jul 31, 2020 Acceptance: Aug 28, 2020 Publication: Aug 37, 2020 Process: Peer-reviewed 
to the policies of the Institute of Diagnosis and Epidemiological reference.

We searched the patients' charts for the following variables: Date of admission, age, gender, multimorbidities, time between symptom onset and the initiation of treatment, animal contact, previous tick bites, signs, symptoms, and laboratory tests (Table 1). Delayed treatment was defined as the initiation of treatment .5 days after the beginning of symptoms.

Information was analyzed with MiniTab statistical package version 19.2.0 and with the aid of Microsoft Office Excel (2018). Spearman's correlation coefficient was used to interpret all data. The study was approved by the Institutional Review Board of the General Hospital of Mexicali.

\section{Results}

A total of 129 hospitalized patients' records were included, all diagnosed with Rocky Mountain Spotted Fever confirmed by PCR (Table 1). There were 71 males ( $55 \%$ ) and 58 women ( $45 \%$ ) with age ranging between 1-67 years old, with a mean of 25 years From the patient total, $58 \%$ were diagnosed during summer (April-September), and $42 \%$ during winter (October-March). Forty-one patients died, from which $51 \%$ were females, not showing a statistical difference between genders. We compared mortality among patients admitted who were $\leq 20$ years of age with that among patients $>21$ years of age, the latter being higher with an Odds Ratio (OR) of 4.2 (95\% Confidence Interval [95\% Cl]: $1.86-$ 9.78, $\mathrm{p}=0.0001)$. One hundred five patients were tested for serum electrolytes, $71 \%$ developed hyponatremia $(<135 \mathrm{mEq} / \mathrm{L})$. Mortality rate in patients with hyponatremia was $34 \%$, compared to those who did not have hyponatremia for an $0 \mathrm{R}$ of $1.7(95 \% \mathrm{Cl} 0.6-4.6 ; \mathrm{p}=0.13)$ not statistically significant.

From the 51 patients with delayed treatment, 17 cases were fatal (33\%) (OR $1.37,95 \% \mathrm{Cl} 0.6-3.11 ; \mathrm{p}=0.2$ ). When comparing the group of patients who received delayed treatment against those who received early treatment ( $\leq 5$ days after the onset of symptoms), mortality rate for patients who received delayed treatment was $33 \%$, with an OR of 1.37 (95\% Cl 0.6-3.11)

We gathered platelet levels from 111 patients, where 99 patients $(76 \%)$ presented with thrombocytopenia below 150,000 cells (OR $6.01,95 \% \mathrm{Cl}$ $0.7-48, p=0.02)$, in comparison to those who did not develop thrombocytopenia.

A total of 100 patients presented exanthema, from which 31 died, with an $0 R 0.8(95 \% \mathrm{Cl}, 0.3-2.04 ; \mathrm{p}=0.3)$ without representing a risk factor for mortality. Skin necrosis of the limbs is a known complication, which was present in 9 patients from our sample ( $7 \%)$. Six of them died $(67 \%)$ OR 4.6 ( $95 \% \mathrm{Cl} 1.1-20, \mathrm{p}<0.02)$.

Acute kidney injury (considered as a creatinine value $>1.5 \mathrm{mg} / \mathrm{dL}$ based on the KDIGO criteria for Acute Kidney Injury) is a risk factor associated with higher mortality rate ( $0 \mathrm{R} 9,95 \% \mathrm{Cl} 3.4-23.5, \mathrm{p}<0.001)$. Neurological dysfunction was present in 68 patients $(53 \%)$, from which $26(38 \%)$ died (OR $1.8,95 \% \mathrm{Cl}, 0.88-4 ; \mathrm{p}=0.05$ ).

A higher incidence was recorded during the months of July and September, with a total of 42 patients (33\%), and a fatal outcome in 12 of them $(28 \%)$, in comparison to the rest of the months where the incidence was $19-23 \%$.

\section{Discussion}

RMSF has a rising incidence in northwestern regions of México, where the weather mainly consists of two seasons, summer (April-September) and winter (October-March). Those who did not receive treatment had a $30 \%$ mortality, which could be reduced to $15 \%$ with treatment. ${ }^{7-8}$ In this study there were 129 patients, all diagnosed with a confirmatory test by PCR.

Table 1. Characteristics of patients with RMSF + admitted to the General Hospital of Mexicali $(n=129)$

\begin{tabular}{|c|c|c|c|c|c|c|}
\hline Demographic & Total (\%) & Fatal & Non-fatal & \% Lethal & OR $(95 \% \mathrm{Cl})$ & $\mathrm{p}$-value \\
\hline Male & 71 (55) & 20 & 51 & 28 & Ref & \\
\hline Female & $58(44.9)$ & 21 & 37 & 36 & $0.69(0.3-1.4)$ & \\
\hline Age & Total & Fatal & Non-fatal & $\%$ Lethal & $\mathrm{OR}$ & \\
\hline$<20$ years & $61(47.2)$ & 10 & 51 & 16 & Ref & \\
\hline$>20$ years & $68(52.7)$ & 31 & 37 & 45 & $4.27(1.86-9.78)$ & $<0.0001$ \\
\hline Hyponatremia & $68(71.4)$ & 23 & 45 & 34 & $1.7(0.6-4.6)$ & \\
\hline Thrombocytopenia & $99(76.7)$ & 35 & 64 & 35 & $6.01(0.7-48)$ & \\
\hline $\begin{array}{l}\text { Delayed treatment } \\
(>5 \text { days })\end{array}$ & $51(39.5)$ & 17 & 34 & 33 & $1.37(0.6-3.11)$ & \\
\hline Rash & $100(77.5)$ & 31 & 69 & 31 & $1.1(0.35-2.04)$ & \\
\hline Necrosis & $9(6.97)$ & 6 & 3 & 66 & $4.8(1.1-20)$ & $<0.02$ \\
\hline Neurological dysfunction & $68(52.7)$ & 26 & 42 & 38 & $1.8(0.88-4)$ & \\
\hline Elevated creatinine & $52(40.3)$ & 29 & 23 & 55 & $9(3.4-23.5)$ & $<0.001$ \\
\hline Cases per month & Total & Fatal & Non-fatal & \% Lethal & & \\
\hline Jan-Mar & $30(23.2)$ & 9 & 21 & 30 & & \\
\hline Apr-Jun & $33(25.5)$ & 12 & 21 & 36 & & \\
\hline Jul-Sep & $42(32.5)$ & 12 & 30 & 28 & & \\
\hline Oct-Dic & $24(18.6)$ & 8 & 16 & 33 & & \\
\hline
\end{tabular}

Legend: † Rocky Mountain Spotted Fever 
There was a $32 \%$ mortality rate, twice as much as those reported by previous studies in México.3, 8 This high mortality rate in treated patients can be explained because patients that were hospitalized were more severe than those who received ambulatory treatment. Treatment initiation delay is not related with a high mortality rate, unlike the 2016 study. ${ }^{3}$ Mortality is also related to the presence of skin necrosis of the limbs with an OR 4.6, a variant not considered in the previous study. 3 RMSF in hospitalized patients has a high mortality rate in spite of early treatment in all age groups, without showing any predominance in gender 9 . However, patients older than 20 years of age had a higher mortality rate than those younger than 20 years, without any predominance in gender. Acute kidney injury, skin necrosis of the limbs, and age older than 20 years were predictors of mortality. Thrombocytopenia was also a risk factor for higher mortality rate, yet, only one patient without thrombocytopenia died. Such a small sample makes it almost impossible to define its risk accurately.

Regarding treatment, tetracyclines have been the only accepted treatment for RMSF for many years, however, the medical community is in need of alternative solutions just as effective as doxycycline, but these may require future research.? 


\section{References}

1. Snowden S, Simonsen KA. Rickettsia Rickettsiae (Rocky Mountain Spotted Fever). StatPearls Publishing; 2020.

2. Sanchez-Montes S, Lopez-Perez AM, Guzman-Cornejo C, Colunga-Salas P, Becker I, Delgado-de la Mora- J, et al. Rickettsia parkeri in Dermacentor parumapertus Ticks, México. Emerg Infect Dis. 2018 Jun;24(6):1108-1111.

3. Álvarez-Hernández G, Candia-Plata MC, Delgado-de la Mora J, Acuña-Melendrez NH, Vargas-Ortega AP, Licona-Enríquez JD. Fiebre maculosa de las Montañas Rocosas en niños y adolescentes mexicanos: cuadro clinico y factores de mortalidad Salud Publica Mex 2016;58:385-392. Spanish.

4. Pavanelo DR, Schroder NCH, Pin Viso ND, Martins LA, Malossi CD, Galleti MFBM, et al. Comparative analysis of the midgut microbiota of two natural tick vector of Rickettsia rickettsia. Dev Comp Immunol. 2020; 106:103606.

5. Barba JR. Fiebre manchada de las Montañas Rocosas. Revista Mexicana de Patologia Clinica. 2009; 56(3):193-208. Spanish.

6. Parola P, Paddock CD, Socolovschi C, Labruna MB, Mediannikov 0, Kernif T, et al. Update on Tick-Borne Rickettsioses around the World: a Geographic Approach. Clin Microbiol Rev. 2013;26(4):657-702.

7. Traeger MS, Regan JJ, Humpherys D, Mahoney DL, Martinez M, Emerson GL, et al. Risk Factors for Fatal Outcome From Rocky Mountain Spotted Fever in a Highly Endemic Area-Arizona, 2002-2011. Clin Infect Dis. 2015; 60(11):1659-66.
8. Jaramillo HJ, Rodriguez M. Ricketsiosis. Presentacion de dos casos, en medio de un brote en Mexicali, Baja California. Medicina Interna de México. 2010; 26(2):180-2. Spanish.

9. Paddock CD, Denison AM, Lash RR, Liu L, Bollweg BC, Dahlgren FS Phylogeography of Rickettsia rickettsii Cenotypes Associated with Fatal Rocky Mountain Spotted Fever. Am J Trop Med Hyg. 2014;91(3):589-97.

10. Gottlieb M, Long B, Koyfman A. The Evaluation and Management of Rocky Mountain Spotted Fever in the Emergency Department: a Review of the Literature. J Emerg Med. 2018 Jul;55(1):42-50.

11. Moore JJ. Time relationships of the wood-tick in the transmission of Rocky Mountain spotted fever. J Infect Dis 1911; 8: 339-47.

12. Ramos-e-Silva M, Pereira AL. Life Threatening Eruptions Due to Infectious Agents. Clin Dermatol. 2005; 23(2):148-56.

13. Denison AM, Amin BD, Nicholson WL, Paddock CD. Detection of Rickettsia rickettsii, Rickettsia parkeri, and Rickettsia akari in skin biopsy specimens using a multiplex real-time polymerase chain reaction assay. Clin Infec Dis. 2014; 59(5):635-642.

14. Centers for Disease Control and Prevention. Available from: https://www.cdc.gov/dpdx/ticks/index.html. Atlanta: c2019. Cited Nov 19, 2019.

15. Ed. E. Maxey, G T McCullough, J W Leary. Some Observations on the So-called Spotted Fever of Idaho. 1st ed. 1899.

\section{Acknowledgments}

We would like to acknowledge the General Hospital of Mexicali for allowing us to continue researching within its premises

Conflict of Interest Statement at Funding

The Authors have no funding, financial relationships or conflicts of interest to disclose.

\section{Author Contributions}

Conceptualization: HJJR, and RRL. Methodology: HJJR. Validation: JLP, and FMY. Formal Analysis: HJJR, JJHR, and FMMG. Data Curation: LAGB. and ERGV. Investigation: HJJR, JJHR, FMMG, LAGB, and ERGV. Resources: JJHR, FMMG, LAGB, ERGV, and JABL. Writing - Original Draft: HJJR, JJHR, FMMG, and LAGB. Writing - Review at Editing: HJJR, JJHR, and FMMG. Visualization: JJHR, and FMMG. Supervision: RRL. Project Administration: HJJR.

Cite as:

Jaramillo-Ramírez HH, Hernández-Ríos JJ, Martínez-González FM, Gutiérrez-Bañales LA, García-Valenzuela ER, Beltrán-López JA, et al. Prognostic Factors in Patients with Rocky Mountain Spotted Fever. Int J Med Students. 2020 May-Aug;8(2):107-110.

This work is licensed under a Creative Commons Attribution 4.0 International License

ISSN 2076-6327

This journal is published by the University Library System, University of Pittsburgh as part of the Digital Publishing Program and is co-sponsored by the University of Pittsburgh Press. 